\title{
The impact of the multi-channel retail mix on online store choice: Does online experience matter?
}

\begin{abstract}
More and more grocery retailers are becoming multi-channel retailers, as they are opening an online alternative next to their traditional offline supermarkets. While the number of multichannel grocery shoppers is also expanding at a fast growth rate, there are still large differences in online shopping frequency, and as a result, in the levels of experience with buying in the online grocery channel. This study wants to (i) identify the underlying drivers of online store choice and (ii) explore if and how these drivers change when multi-channel shoppers gain online grocery shopping experience. We investigate this question with an online store choice model using purchase data of an extensive UK household panel over a two-year period, covering all multi-channel retailers in the grocery market. Our results show that multi-channel shoppers, at the start of online grocery shopping, tend to select the online store belonging to the same chain as their preferred offline store, especially when the online store is strongly integrated with the offline store in terms of assortment. When online grocery shopping experience increases, multichannel shoppers' focus shifts from a comparison within a chain across channels to a comparison across chains within the online channel, resulting in an increasing importance of online assortment attractiveness and online loyalty when choosing an online store.
\end{abstract}

Keywords: online store choice; online buying experience; multi-channel retailing; grocery shopping; store loyalty 


\section{Introduction}

Multi-channel and online retailing are becoming increasingly important in the rapidly changing retail environment, resulting in an increasing number of store-based retailers that add an online store to their portfolio (e.g., Carini, Vikram, Patti, \& Doug 2011; Dawes \& Nenycz-Thiel 2014; Neslin et al. 2006; Neslin \& Shankar 2009; Zhang et al. 2010). Within the grocery retail sector, multi-channel retailing tops the agenda of all major grocery retailers as more shoppers surf the Web to buy consumer packaged goods (Warschun 2012). In the US, for instance, online grocery sales are $3.3 \%$ of total grocery spending and are expected to rise to $11 \%$ by 2023 (Steiman 2014). Questions even arise concerning stores that are not involved in multi-channel retailing. In 2013, when Morrisons was not yet active in the online grocery market, Bill Grimsey (former chief executive of Wickes, Iceland and Focus DIY) said: "Do Morrisons have a choice to stay out of the online food shopping business? The answer is unequivocally no. If they don't, Tesco, Sainsbury's and Asda will be taking shoppers [Morrisons] could have earned." (as cited in Rankin, The Guardian, 8 March 2013, p.41).

An important motivation to add an online alternative is indeed that the extra online service can increase customer satisfaction and loyalty, and help to retain existing customers (IGD 2012; Zhang et al. 2010). This might lead to increased chain sales and profits (Mulpuru, Seghal, Freeman Evans, Hoar, \& Roberge 2012). Much depends, however, on the factors multi-channel shoppers use to choose the online store, and how these store choice drivers evolve when gaining more experience. Initially, it can be expected that multi-channel shoppers are inclined to choose the online store belonging to the same chain as their favorite offline store when going online (Dawes \& Nenycz-Thiel 2014). The less familiar online shopping environment and higher perceived risk of online purchases may lead these shoppers to rely on their offline store 
experiences and preferences when choosing an online store for the first time. While offline store reliance can play a major role in store choice decisions when multi-channel shoppers start buying groceries online, other store choice factors are expected to become more important when consumers gain more online buying experience. In particular, the online environment greatly facilitates store comparison on traditional store choice factors (Degeratu, Rangaswamy, \& Wu 2000; Brynjolfsonn \& Smith 2000), such as price and assortment. This may lead to the selection of - or encourage shifts to - online stores of competitive chains. This effect of (simplified) online store comparison may, however, only materialize after some time, when the uncertainty of buying in the relatively new online channel is reduced by an increase in online grocery shopping experience.

Our main research question is therefore twofold: (i) identify and empirically investigate the effect of the multi-channel retail mix (offline- and online-based store choice drivers) on online store choice and (ii) explore if and how these drivers change when multi-channel shoppers gain experience (investigation of the moderating effect of online grocery shopping experience). To examine these research questions, we have access to a rich data set comprising purchase data of an extensive UK household panel for all grocery retailers, over a two-year period. We use a multinomial logit model to analyse online store choice decisions, their underlying drivers and the moderating effect of experience.

This study contributes to the existing retailing and multi-channel literature in several ways. While there have been a variety of studies focusing on one or several store choice drivers when studying offline or online store choice (e.g., Bell, Ho, \& Tang 1998; Briesch, Chintagunta, \& Fox 2009; Dawes \& Nenycz-Thiel 2014; Fox, Montgomery, \& Lodisch 2004; Gijsbrechts, Campo, \& Nisol 2008; Gupta \& Kim 2007; Kim \& Gupta 2009; Tang, Bell, \& Ho 2001; 
Verhagen \& Van Dolen 2009), we are - to the best of our knowledge - the first to systematically investigate (i) a large set of antecedents on online store choice, (ii) across multiple multi-channel retailers (iii) within the grocery sector, thereby (iv) considering the moderating role of customer experience. Previous online store choice studies focused on online store choice for one retailer and/or were carried out in other sectors than the grocery sector. As grocery shopping differs substantially from other purchase contexts (habitual purchase patterns, use of choice heuristics and decision cues; Hoyer, MacInnis \& Pieters 2013), findings of these studies are therefore not directly transferrable to, and provide little insight into what drives online store choice. Moreover, these studies do not take into account that, for grocery purchases, most online shoppers are multi-channel shoppers, who visit both the online and offline channel. The scarce number of previous studies that did focus on online grocery shopping (Chu, Chintagunta, \& Cebollada 2008; Chu, Arce-Urriza, Cebollada, \& Chintagunta 2010; Dawes \& Nenycz-Thiel 2014; Gupta \& Kim 2007; Kim \& Gupta 2009) looked at a small set of antecedents, not taking into account offline store preference or the comparison between offline and online marketing mix instruments. But, offline store preference and channel integration (i.e., similarity) of marketing mix instruments such as price and assortment, can play an important role in consumers' online store choice decisions. We further add to the literature by examining the moderating effect of online grocery buying experience on the store choice criteria that are used, and the possible shift in online store choice that this can entail. Prior research already pointed out that some online store choice drivers may become more or less important over time (Gupta \& Kim 2007; Kim \& Gupta 2009), and that cross-store shopping can increase over time (Dawes \& Nenycz-Thiel 2014), but a systematic and empirical research on this matter is currently lacking. 
From a managerial point of view, our results provide useful insights for retailers who have adopted - or consider shifting to - a multi-channel strategy. More specifically, our research provides (i) a better understanding of whether offline loyal customers will stay with the chain when starting to buy groceries online, and (ii) guidelines on how to adjust the multi-channel retail mix to retain these (offline loyal) consumers and attract new customers to the online store, taking the complex interplay of online competition and the need for cross-channel marketing mix integration into account. Moreover, our results will provide insights on how store choice drivers are influenced by the consumers' online buying experience, allowing multi-channel retailers to differentiate their communication strategy (e.g., stressing comparison with the offline store vs. highlighting marketing mix differences across several online stores) across first-time/starting and experienced online grocery shoppers.

The structure of the article is as follows: in the next section we provide a conceptual framework of online store choice drivers and experience effects; subsequently the model formulation with the different model components is explained; then the data are described and results are presented. The final part provides a summary of the findings, a discussion of managerial implications and suggestions for further research.

\section{Online store choice drivers}

In our conceptual framework we (i) identify the impact of the multi-channel retail mix (i.e., offline- and online-based drivers) on online store choice decisions, and (ii) indicate how the importance of different types of drivers can change as multi-channel shoppers gain more online buying experience. Figure 1 visualizes our conceptual framework.

[Insert Figure 1 about here] 
Table 1 gives an overview of the previous state-of-the-art on antecedents that influence offline store choice (based on offline store choice literature) and online store choice (based on online and multi-channel literature). Most of these studies start from a cost-benefit framework to explain consumers' shopping decisions, and make a distinction between different types of benefits and costs that drive these decisions (e.g., Bawa \& Gosh 1999; Bell et al. 1998; Gijsbrechts et al. 2008). In line with these studies, we assume that consumers decide to choose an online grocery store that maximizes the overall utility derived from shopping at that store on a given shopping trip. We distinguish between variable and fixed shopping utility, and take into account shopping benefits as well as costs (e.g., Bell et al. 1998, Tang et al. 2001). Variable shopping utility varies with the size and composition of the shopping basket, whereas fixed shopping utility is the same for each shopping trip, irrespective of the number and type of products that are purchased on the shopping trip (e.g., Gijsbrechts et al. 2008; Bawa \& Gosh 1999). Consumers make a trade-off between fixed and variable utility, depending on category demand in size and composition (Bell et al. 1998, Briesch et al. 2009, Gijsbrechts et al. 2008). For instance, trade-offs exist between lower prices and less convenient locations (e.g., Bell et al. 1998) or larger assortment and longer travel distance to the store (e.g., Briesch et al. 2009; Grewal, Kopalle, Marmorstein \& Roggeveen 2012). As summarized in Table 1, variable shopping utility is determined by price and assortment of the focal store, and marketing mix integration (i.e., the similarity between price and assortment of different store outlets, e.g., the online and offline channel), whereas fixed shopping utility is influenced by the loyalty to the focal store and the transfer of preferences from the offline outlet of the store. ${ }^{1}$

\footnotetext{
${ }^{1}$ Studies on offline store choice, like Bell et al. (1998) and Briesch et al. (2009), also point to distance to the store as an important store choice factor. However, whereas physical distance plays a dominant role in the choice of an offline store (Briesch et al. 2009), it is less relevant for online store choice decisions (Brynjolfsson \& Smith 2000), especially when online stores only offer the home-delivery service (as is the case in our empirical study). Instead of
} 
[Insert Table 1 about here]

While each of the previously discussed drivers as listed in Table 1 can influence multichannel shoppers' online store choice decisions, the relative importance of these drivers can change over time as consumers gain more online buying experience. Prior research did not pay much attention to possible changes in the online shopping process over time (limited research on changing price and convenience effects on purchase intention; cf. Gupta \& Kim 2007; Kim \& Gupta 2009). Our study provides a more complete analysis of online store choice drivers (see last row Table 1).

\section{Drivers of multi-channel shoppers' online store choice decisions}

According to the offline store choice literature, a store's price level (cost) and assortment attractiveness (benefit) are key factors determining the store’s variable shopping utility (Bell et al. 1998; Briesch et al. 2009; Pan \& Zinkhan 2006). Even though some online and multi-channel studies on in-store decisions in grocery settings report that price sensitivity is less pronounced online (e.g., Chu et al. 2008; Degeratu et al. 2000), the effect of price on online decisions like category purchase incidence, brand choice and online purchase intention is still found to be negative (Andrews \& Currim 2004; Chu et al. 2008; Degeratu et al. 2000; Kim \& Gupta 2007; Verhagen \& Van Dolen 2009). In the same line and as can be expected, empirical research confirmed that assortment is an important factor of store loyalty and purchase intention in an online shopping context (Koo 2006; Verhagen \& Van Dolen 2009). We therefore expect that through their effect on perceived variable shopping utility - online price will have a negative

distance, home delivery fees could constitute an important component of fixed shopping costs in an online context (Tang et al. 2001). Unfortunately, we have no information on the online stores' fixed shopping fees, and therefore treat it as a component of 'intrinsic utility’ (see Model section). This also holds for other shopping environment antecedents like website design that could influence online store choice but for which we, unfortunately, have no information on and/or not enough variation in our data. 
effect and online assortment attractiveness a positive effect on the probability that the online store will be selected (see Figure 1).

In addition to these traditional price and assortment variables, the multi-channel literature points to the importance of taking possible integration effects of online-offline price levels and assortments into account as they can play a role in determining consumers' multi-channel shopping decisions (Berger, Lee \& Weinberg 2006; Neslin et al. 2006, Verhagen \& Van Dolen 2009). In contrast with other online traded products (such as music and apparel), grocery assortments tend to be smaller and prices higher in the online compared to the offline channel (for reasons such as extra operational costs and crucial importance of fast delivery times) (Cheng 2010). Stronger channel integration (i.e., smaller channel differences in terms of assortment and price - smaller online assortment reductions and lower online price premiums) will therefore increase the store's online variable shopping utility. In contrast, when online stores differ more from their offline counterpart of the same chain (e.g., higher online price premiums: Grewal et al. 2010; larger online assortment reductions: Cheng 2010), this not only reduces the expected value of online purchases (benefit/cost ratio), but may also increase uncertainty about the online store's variable shopping utility. Overall, we therefore expect that stronger channel integration in price and assortment will have a positive effect on online store choice (see Figure 1).

Regarding fixed shopping utility, store loyalty to a particular store was shown to have a strong positive impact on offline store choice decisions for that store (Bell et al. 1998; Briesch et al. 2009). For repeat and multi-category purchases, such as groceries, most shoppers tend to revisit the same store(s), not only because they develop a preference for the store, but also because familiarity with the store reduces in-store search and effort costs (see e.g., Briesch et al. 2009; Rhee \& Bell 2002). In an online shopping context, the tendency to revisit the same online 
store might be less strong because of lower switching costs compared to the offline channel (e.g., easier price and assortment comparison, no travelling needed) (Brynjolfsson \& Smith 2000). For many durable goods, this has indeed resulted in increased price (and assortment) comparison and intensified competition (Zettelmeyer, Morton \& Silva-Risso 2006). But, other research on online store loyalty effects in non-grocery sectors already found that online store loyalty can reduce the likelihood that consumers will search for alternative (online) stores (Johnson, Moe, Fader, Bellman, \& Lohse 2004). Within the grocery shopping context where purchase involvement tends to be low and consumers have to buy multiple products during a single store visit, this effect is even more likely to be present as many of the factors driving consumers to revisit the same offline store(s) still hold in the online context (such as familiarity advantages of 'known' online stores' websites and a preference to minimize search and effort costs). Consequently, we expect that online store loyalty will have a substantial and positive effect on online store choice (see Figure 1).

For similar reasons (namely familiarity benefits and lower chain 'switching' costs), and because consumers can transfer store preferences from the offline to the online channel, offline store preference can be an important driver of online store choice (Dawes \& Nenycz-Thiel 2014). Given that trust is an important determinant for online shopping (e.g., Gefen, Karahanna, \& Straub 2003), and that consumers may feel less uncertain toward an online grocery store carrying the same chain name as (one of) their favorite offline store(s), offline store preference can have a positive effect on the perceived online store’s fixed utility (Verhagen \& Van Dolen 2009), and increase the probability that an online store of the same chain will be selected (see Figure 1). 


\section{Moderating effect of online buying experience}

We rely on insights from the online and multi-channel literature to explain the weakening or reinforcing effect of experience (i.e., the changes in importance weights of store choice drivers) on online store choice decisions. Consumers, who start buying a specific product in the online channel, can be uncertain about their online purchase decision (Gefen et al. 2003). Especially for low-involvement products, such as groceries, they may therefore rely on decision cues that help to simplify the online shopping process, such as similarity to more familiar offline alternatives. Offline store preference (i.e., a positive attitude toward a familiar offline store) and stronger channel integration of the chain's price and assortment (i.e., smaller price and assortment differences across the online and offline store) can for that reason be especially helpful in the initial phases of online shopping. As consumers gain more experience with buying the products online, the impact of these offline-based drivers may gradually become less important, because consumers start to feel more confident in the online shopping environment, better able to evaluate different online alternatives, and less dependent on their offline shopping experience as an information cue (Dawes \& Nenycz-Thiel 2014; Hogarth \& Einhorn 1992; Montoya-Weiss, Voss, \& Grewal 2003). The effect of offline store preference and online-offline integration in price and assortment is therefore expected to diminish as online buying experience for groceries increases. Otherwise stated, we expect that online buying experience will have a weakening moderating effect on the impact of offline-based drivers (offline store preference, assortment integration, price integration) on online store choice (see Figure 1).

While the effects of offline-based drivers on online store choice is expected to decline as consumers gain more online grocery shopping experience, we expect multi-channel shoppers to shift from a comparison within a chain across channels (offline vs. online) to a comparison 
within the online channel across (online) chains. As shopping experience contributes to consumer knowledge (Alba \& Hutchinson 1987; Rose, Clark, Samuel, \& Hair 2012), the evaluation process can evolve to a more elaborate evaluation of a larger set of online store alternatives on important online store attributes, being price and assortment (Alba \& Hutchinson 1987; Rose et al. 2012). Dawes and Nenycz-Thiel (2014) indeed find that the extent of retailer cross-purchasing changes over time, and that there is an increasing tendency of consumers to purchase from multiple online retailers. We therefore expect that the impact of online price and assortment attractiveness on online store choice will become more important as knowledge on how to make purchase decisions in an online grocery store and how to evaluate different online stores on online store attributes increases with online grocery shopping experience. For similar reasons, we expect that there will be a shift in impact of offline store preference to online store loyalty, as more online buying experience reduces the need to rely on offline store preference as an indicator, and repeated positive experiences with a specific online store may create satisfaction and enhance the importance of online store loyalty (Shankar, Smith \& Rangaswamy 2003). Hence, online buying experience is expected to have a reinforcing moderating effect on the impact of online-based drivers (online price, online assortment, online store loyalty) on online store choice (see Figure 1).

\section{Methodology}

Building on random utility maximization principles (e.g., Bell et al. 1998; Briesch et al. 2009; Gijsbrechts et al. 2008; Tang et al. 2001), we use a multinomial logit model to analyse online store choice, its underlying drivers and the moderating effects of experience. A household $h$ is assumed to select the online store $s(\mathrm{~s}=1,2, \ldots, \mathrm{S})$ on online shopping trip $v$ that provides the 
highest utility $\left(\right.$ Utility $\left._{h s v}\right)$. The probability that an online store $s$ is chosen by household $h$ on shopping trip $v\left(\operatorname{Pr}\left(y_{h s v}=1\right)\right)$ is given by:

$$
\operatorname{Pr}\left(y_{h s v}=1\right)=\frac{\exp \left(\text { Utility }_{h s v}\right)}{\sum_{j=1}^{S} \exp \left(\text { Utility }_{h j v}\right)}
$$

with,

(2) Utility $_{h s v}=\left[\alpha_{s 1}+\alpha_{s 2}\right.$ Experience $_{h v}+\alpha_{s 3}$ Trend $\left._{v}\right]+$

$$
\begin{aligned}
& {\left[\beta_{1} \text { Price }_{h s v}+\beta_{2} \text { Assortment_size }_{h s}+\beta_{3} \text { Assortment_composition }_{h s}+\right.} \\
& \beta_{4} \text { Price_integration }_{h s v}+\beta_{5} \text { Assortment_integration }_{h s}+\beta_{6} \text { Online_loyalty }_{h s v}+ \\
& \beta_{7} \text { Offline_store_preference }_{h s}+\beta_{8} \text { Offline_store_preference }_{h s} * \text { Price_integration }_{h s v}+ \\
& \left.\beta_{9} \text { Offline_store_preference }_{h s} * \text { Assortment_integration }_{h s}\right]+ \\
& {\left[\gamma_{1} \text { Experience }_{h v} * \text { Price }_{h s v}+\gamma_{2} \text { Experience }_{h v} * \text { Assortment_size }_{h s}+\gamma_{3} \text { Experience }_{h v} *\right.} \\
& \text { Assortment_composition }_{h s}+\gamma_{4} \text { Experience }_{h v} * \text { Price_integration }_{h s v}+\gamma_{5} \text { Experience }_{h v} * \\
& \text { Assortment_integration }_{h s}+\gamma_{6} \text { Experience }_{h v} * \text { Online_loyalty }_{h s v}+\gamma_{7} \text { Experience }_{h v} * \\
& \text { Offline_store_preference } \left._{h s}\right]+\varepsilon_{h s v} .
\end{aligned}
$$

In accordance with our conceptual framework, online store utility depends on intrinsic utility (first square brackets), the fixed and variable utility when the household has no prior experience online (second square brackets), and the changes in fixed and variable utility in correspondence with growing experience of the household with the online channel (third square brackets).

To capture intrinsic utility effects (first square brackets), we include store-specific intercepts $\left(\alpha_{\mathrm{s} 1}\right)$, and allow for experience-driven (Experience $\left.{ }_{h v}\right)$ and time-dependent $\left(\right.$ Trend $\left._{v}\right)$ changes in intrinsic attractiveness of the stores. These variables capture the effect of characteristics that differ across stores (and possibly over time) but for which we have no information (like website design, waiting time, costs of delivery). 
In the second square brackets, we include variables affecting a household's variable and fixed shopping utility when the household has no prior experience online. More particularly, we include the following variable utility factors: the online price level of store $s$ on shopping trip $v$ $\left(\text { Price }_{h s v}\right)^{2}$, the assortment attractiveness - where we distinguish between the size of the online assortment (measured as the number of brands of store $s$ over the observed time period, Assortment_size $_{h s}$ ) and online assortment composition (measured as the availability of favorite brands, Assortment_composition ${ }_{h s}$ ) (cf. Briesch et al. 2009), and marketing mix integration in terms of price and assortment size between the online and offline alternative of the same chain (Price_integration $_{h s v}$ and Assortment_integration ${ }_{h s}$ ). We include two variables to capture fixed utility effects. Online store loyalty (Online_loyalty ${ }_{h s v}$ ) is a dynamic loyalty variable, measuring household $h$ 's tendency to revisit the same online store $s$ over time (see also Guadagni \& Little 2008). Offline store preference (Offline_store_preference ${ }_{h s}$ ) is a static variable that captures the transfer effect of household h's preference (operationalized as share-of-wallet) for the offline store belonging to the same chain as online store $s$. The brand extension literature has demonstrated that the likelihood or strength of a transfer of a positive attitude to/preference for a familiar alternative to a new or less familiar alternative that is introduced under the same (brand) name can depend on the similarity or fit between the familiar and new alternative (e.g., DelVecchio 2000; Bottomley \& Holden 2001; Völckner \& Sattler 2006). To control for this mechanism, we also include interaction effects between offline store preference and the two marketing mix integration variables.

The third square brackets capture the moderating effects of experience by means of interaction terms between online grocery buying experience (Experience ${ }_{h v}$ ) on the one hand, and

\footnotetext{
${ }^{2}$ All variables, except the time trend, are made household-specific to partly control for (observed) household heterogeneity. See the Data section for more details on the specific operationalization.
} 
the different online store choice drivers on the other hand (price, assortment size, assortment composition, price and assortment integration, online loyalty and offline store preference). Coefficients $\gamma_{k}$ that have the same (different) sign as the main effect of online store choice driver $\mathrm{k}$ point to a reinforcing (weakening) effect of experience on the impact of this driver (see Conceptual Framework section and Figure 1).

Finally, we account for unobserved household heterogeneity by making the main (i.e., the second square brackets) and interaction effects (i.e., the third square brackets) of the online store drivers random over households.

\section{Data}

\section{Panel data set}

We have data from a representative UK household panel from Kantar Worldpanel obtained from AiMark for the period starting January 2007 till December 2008. ${ }^{3}$ The UK online grocery market is, from all major online grocery markets, the most developed one and was one of the leading markets in 2007-2008, which is in the UK grocery market a stable period in terms of mergers and acquisitions (Nielsen 2012; Warschun 2012). As a study of ATKearney points to a major growth potential for online grocery shopping for countries with similar characteristics as the UK, such as the US or major European markets like Germany (Warschun 2012), the results of our study are useful for markets which are evolving to the same levels as the UK online grocery market. Our data cover 104 weeks of household grocery purchases in all UK grocery chains (online and offline). The market share of the four online grocery stores in the UK market in this period -

\footnotetext{
${ }^{3}$ The panel consists of a sample of approximately 34,000 households that is representative for the UK market. Kantar Worldpanel constantly monitors the representativeness of the panel and tracks purchase behavior of the panel members over time (http://www.kantarworldpanel.com/global).
} 
Tesco, Asda, Sainsbury's and Waitrose - equals approximately $6 \%$ of the total grocery market sales. Within that time period, each of the four chains offered a home-delivery, but no pick-up, service. Figure 2 illustrates that Tesco has the largest and Waitrose has the smallest market share in both the offline and online channel. From 2007 to 2008, the online market share of both Waitrose and Asda increased, while Tesco's online market share decreased.

[Insert Figure 2 about here]

\section{Store choice and purchase behavior descriptives}

More than 10,000 panel members ( $30 \%$ of the total panel) visited the online channel of one of the four multi-channel retailers during the observation period. From this group of multi-channel shoppers, we retained households that (i) made their first online grocery purchases during the examined period ('new' online grocery shoppers), (ii) participated in the panel up to 6 months before their first online grocery shopping trip (initialization period) ${ }^{4}$, and (iii) shopped more than once online in our two year time frame (excluding 'pure' trial purchases; see Campo, Breugelmans \& He 2014 for a similar approach).

Table 2 illustrates the shopping pattern (in the online and offline channel) of the 3,234 retained multi-channel households and contrasts this with the shopping pattern (in the offline channel) of all single-channel households shopping in the same period. ${ }^{5}$ The shopping frequency (the number of monthly shopping trips) of multi-channel households is lower online ( $\mathrm{M}=1.62$, $\mathrm{SD}=1.03$ ) than offline $(\mathrm{M}=6.89, \mathrm{SD}=6.01)$ and single-channel households have an even higher offline shopping frequency ( $\mathrm{M}=7.10, \mathrm{SD}=6.01)$. In contrast, multi-channel households spend

\footnotetext{
${ }^{4}$ As every household has a different starting point in online shopping, the initialization period, which is until 6 months before online shopping, depends on that starting point.

${ }^{5}$ The descriptives of the offline channel of the multi-channel shoppers are based on the entire observation period, but results look almost identical when using the period before online shopping only.
} 
more per shopping trip in the online channel $(\mathrm{M}=71.10, \mathrm{SD}=45.11)$ compared to the offline channel (M=28.77, SD=35.61), while single-channel households spend a bit less per shopping trip in the offline channel $(\mathrm{M}=24.97, \mathrm{SD}=46.00)$. This confirms the finding of previous research that multi-channel shoppers are more likely to make major trips in the online channel, while fillin trips are most likely to happen in the offline channel (e.g., Chintagunta, Chu, \& Cebollada 2012). Overall, monthly spending levels for multi-channel shoppers are higher in the offline ( $M=197.97, S D=144.49)$ compared to the online channel $(M=115.13, S D=97.17)$, and higher compared to that of single channel offline shoppers $(M=177.10 ; S D=177.12)$. This in line with Kushwaha \& Shankar's (2013) finding that multi-channel shoppers spend more than singlechannel shoppers.

\section{[Insert Table 2 about here]}

Moreover, multi-channel households visit more chains in the offline channel ( $M=5.43$, $\mathrm{SD}=1.90)$ than single-channel households $(\mathrm{M}=4.45, \mathrm{SD}=2.20)$. The offline allocation pattern (share-of-wallet across multiple offline stores) per multi-channel chain is quite similar for multichannel as for single-channel households. In contrast, online share-of-wallet is higher for Tesco and Waitrose, which is logical as there are fewer retailers that offer an online grocery store and consumers are less likely to visit multiple online chains, yet the ranking remains identical to the offline allocation pattern. Table 2 further shows that the majority of multi-channel shoppers (64.27\%) selects an online store of the same chain as their most preferred offline store during the first purchase. At the same time, this illustrates that multi-channel retailers cannot take the transfer from offline store preference to online store choice as 'given’ since $35.73 \%$ of the consumers does not choose the online store extension of their most preferred offline store. Moreover, not all consumers stay loyal to the online store they selected during the first online 
purchase occasion: $35.62 \%$ shopped at 2 or more online grocery stores during the estimation period and thus switched to another online store compared to the first online store choice. To obtain a better insight into the mechanisms underlying these effects/outcomes, we use a modelbased approach to examine online store choice decisions and their drivers.

\section{Variable operationalization}

Table 3 shows the variable operationalization. To construct store-level price and assortment variables, we select the top 67 categories, covering two third of all purchases made at UK grocery retailers. In line with Briesch et al. (2009), marketing mix variables are made household-specific, by using a weighted sum of category-level variables over the selected categories, with long-term household category purchase shares as weights (cf. Vroegrijk, Gijsbrechts, \& Campo 2013; Zhang \& Breugelmans 2012). For each store, to operationalize the price and price integration variables, we use a period of four weeks (Fox et al. 2004) for both the online and offline channel. Given the low purchase frequencies for some of the brands in the assortment, similar four-week assortment variables could result in 'artificial' changes due to missing values. We therefore decided to keep the assortment measures (size, composition, and integration) stable over time; they only vary across stores and households. ${ }^{6}$ For both integration measures, we use a ratio, comparing the online with the offline store of the same chain (cf. Sullivan 1998). Higher values of this ratio are associated with stronger channel integration for assortment size (i.e., smaller online assortment reduction). However, higher values of the ratio of online to offline prices point to higher online price premiums, and hence, less integration. Therefore, we multiplied the ratio

\footnotetext{
${ }^{6}$ We tested models with different operationalizations of the assortment variables (size, composition and integration; varying per month, bi-month, quarter and half-year, with and without a moving time window). Estimation results with such time varying assortment variables did not result in important model fit improvement, and more importantly, significantly decreased the face validity of assortment variable coefficients, most likely because they capture artificial rather than true variation over time.
} 
of price with (-1) to measure price integration, so that a positive coefficient corresponds to a(n) (expected) positive effect of stronger price integration on online store choice. In line with Leenheer, van Heerde, Bijmolt, and Smidts (2007), offline store preference is a static measure, operationalized as the proportion of expenditures (share-of-wallet) in the offline store belonging to the same chain as the online store $s$ in the initialization period. Online loyalty is a dynamic store-specific measure of previous online purchases in an online store (Guadagni \& Little 2008) and online buying experience is a dynamic measure of the general online grocery shopping experience a household builds up across online stores which is a combination of RFM (recency, frequency and monetary value) factors (based on Ansari, Mela \& Neslin 2008; Buckinx \& Van de Poel 2005; Campo et al. 2014). All retained multi-channel households start grocery shopping for the first time in the estimation period (starting value of zero). For both dynamic measures, a decay parameter is used to capture fading effects, and a grid search procedure was applied to identify the value that provides the best model fit (.7 for online store loyalty and .5 for online buying experience).

[Insert Table 3 about here]

\section{Variable descriptives}

Table 4 provides descriptives of the explanatory variables. For the marketing mix variables (price and assortment), we report the ‘original’ values for each multi-channel retailer, i.e., before applying household-specific weights that correct for differences in category importance between households. Waitrose carries the highest online price level $(\mathrm{M}=.18, \mathrm{SD}=.53)$ (i.e., .18 pound per equivalent unit) and Asda the lowest (M=.12, $\mathrm{SD}=.38)$. Tesco has the largest number of brands ( $\mathrm{M}=66.81, \mathrm{SD}=50.99)$ (i.e., about 67 brands per category) in the online assortment and Waitrose 
the smallest $(\mathrm{M}=36.16, \mathrm{SD}=30.11) .{ }^{7}$ Households can find most of their favorite brands at Tesco $(\mathrm{M}=.57, \mathrm{SD}=.26)$ (i.e., on average, $57 \%$ of favorite brands is available at the store per category) and least at Waitrose $(\mathrm{M}=.33, \mathrm{SD}=.14)$. All retailers have, on average, a higher online price compared to offline price (ratio $>1$ ), which confirms previous findings on channel price differences within the grocery retail sector (Grewal et al. 2010). Waitrose charges the largest online price premiums (low online-offline price integration) (M=1.04, SD=.89), and Asda $(\mathrm{M}=1.01, \mathrm{SD}=.18)$ and Sainsbury’s $(\mathrm{M}=1.01, \mathrm{SD}=.21)$ are close to a price integration. On average, the online assortment is smaller than the offline assortment for all retailers (ratio < 1), which is in line with online grocery retail practices in the US (Cheng 2010). The assortment integration is largest for Waitrose $(\mathrm{M}=.81, \mathrm{SD}=.14)$ (smallest assortment reduction; online assortment contains - on average - $81 \%$ of the offline assortment), and is smallest for Asda $(\mathrm{M}=.60, \mathrm{SD}=0.11)$. Households are most loyal in the online channel for Tesco $(\mathrm{M}=.60, \mathrm{SD}=.40)$ and least for Waitrose $(\mathrm{M}=.07, \mathrm{SD}=.16)$. Offline store preference is also highest for Tesco $(\mathrm{M}=.53, \mathrm{SD}=.37)$ and lowest for Waitrose $(\mathrm{M}=.19, \mathrm{SD}=.27)$.

[Insert Table 4 about here]

\section{Results}

In the next paragraph, we first discuss the estimation results of the online store choice model as described in Equations 1-2, followed by a discussion of the robustness checks we did.

Subsequently, we will also discuss the results of an additional model where we investigate the impact of store choice drivers and experience on online store loyalty.

\footnotetext{
${ }^{7}$ We have defined brand at a relatively low aggregation level. For illustration, Coca Cola Light and Coca Cola Zero in the "soft drinks category" are operationalized as separate brands.
} 


\section{Online store choice model}

Table 5 provides an overview of the estimation results for the online store choice model. ${ }^{8}$ Based on the mean and significant parameter estimates, Tesco experiences the largest intrinsic store utility $\left(\alpha_{\text {Tesco1 }}=.79\right.$, relative to the reference store Sainsbury, $\left.\mathrm{p}<.05\right)$, but also the strongest decrease in intrinsic utility as consumers gain more experience with online grocery shopping $\left(\alpha_{\text {Tesco2 }}=-.01, p<.01\right)$ and the strongest decrease over time $\left(\alpha_{\text {Tesco3 }}=-.01, p<.05\right)$, which is in line with the market shares observed in Figure 2. This can be explained by the tendency of 'unexperienced' online shoppers for whom the favorite offline store does not provide an online alternative, to initially opt for the well-known (online) market leader.

\section{[Insert Table 5 about here]}

The results further show that the main effect (i.e., at zero experience levels) of the variable utility factors is only significant for assortment composition $\left(\beta_{3}=1.59, \mathrm{p}<.01\right)$, and not for assortment size $\left(\beta_{2}=.37, \mathrm{p}>.05\right)$ and price $\left(\beta_{1}=.18, \mathrm{p}>.05\right)$. We also find no significant effect for price integration $\left(\beta_{4}=.46, \mathrm{p}^{>} .05\right)$ and a negative significant effect for assortment integration $\left(\beta_{5}=-4.73, \mathrm{p}<.05\right)$. However, this effect should not be interpreted in isolation as the interaction with offline store preference is positive and significant $\left(\beta_{9}=6.27, \mathrm{p}<.01\right)$. To derive the overall effect and the corresponding significance level of assortment integration for low and high levels of offline store preference, we use the method proposed by Jaccard, Wan, and Turrisi (1990). Table 6 (Panel A) reports the results, and demonstrates that assortment integration is only significant and negative when offline store preference equals zero (and is not significant for offline store preference levels above zero). This is not surprising as consumers that never visit

\footnotetext{
${ }^{8}$ Using a random coefficient specification to account for unobserved heterogeneity leads to a significant model improvement ((Likelihood ratio $\left.\chi^{2}(16)=345.48, \mathrm{p}<.01\right)$ ), while the same substantive findings are obtained.
} 
the offline store of a particular chain will also have a low tendency to visit an online store that is similar in terms of assortment to the offline store.

\section{[Insert Table 6 about here]}

The main effect of the fixed utility components is significant and positive for online store loyalty $\left(\beta_{6}=3.88, \mathrm{p}<.01\right)$, and not significant for offline store preference $\left(\beta_{7}=-2.18, \mathrm{p}>.05\right)$. However, like before, this effect should not be interpreted in isolation and one should take the interaction effects between offline store preference and marketing mix integration into consideration. This interaction effect is significant for assortment integration $\left(\beta_{9}=6.27, \mathrm{p}<.01\right)$, but not for price integration $\left(\beta_{8}=1.14, \mathrm{p}>.05\right)$. Taking the assortment interaction effect into account, Table 6 (Panel C) demonstrates that offline store preference has a significant positive effect on online store choice at all levels of assortment integration. Moreover, as expected, the effect becomes substantially stronger when the online assortment better approximates the offline assortment, thereby confirming that a better assortment integration across channels facilitates the positive transfer effect of offline store preference. ${ }^{9}$

In addition to the variables' main effect, the model includes interaction effects with online buying experience to account for a possible shift in the store choice decision process from a within-chain comparison across channels (offline vs. online) to a within (online) channel comparison across chains (see Figure 1: weakening effect offline-based variables and reinforcing effect online-based variables). The results confirm that as consumers gain more online grocery buying experience, the effect of offline store preference on online store choice decreases $\left(\gamma_{7}=-\right.$ .002 , $\mathrm{p}<.05)$, while the effect of online store loyalty increases $\left(\gamma_{6}=.001, \mathrm{p}<.01\right)$. We find mixed results for the interaction effects with variable utility components. There is no significant

\footnotetext{
${ }^{9}$ The threshold for assortment integration at which offline store preference becomes a significant factor equals .47 (i.e., the online store offers on average per category $47 \%$ of the offline assortment offer). As illustrated in Table 4 , the four online stores of our study offer an assortment that well exceeds this number.
} 
decrease in the impact of the offline/online integration variables: the effect of assortment integration is not significantly affected by online buying experience $\left(\gamma_{5}=-.03, p>.05\right)$, neither does experience have an impact on the already insignificant effect of price integration $\left(\gamma_{4}=-.00\right.$, $\mathrm{p}^{>}$.05). For the online marketing mix variables, we find (as expected) a reinforcing moderating effect of online buying experience on the impact of assortment size $\left(\gamma_{2}=.01, \mathrm{p}<.01\right)$, but no significant effect for assortment composition $\left(\gamma_{3}=.00, \mathrm{p}>.05\right)$ and for online price $\left(\gamma_{1}=.00, \mathrm{p}>.05\right)$. Hence, when consumers gain online shopping experience, they let their store choice decisions depend more on assortment size, but not necessarily more on assortment composition or price. Again using the method proposed by Jaccard et al. (1990), we derive the overall effect (and its corresponding significance level) of assortment size for low and high levels of experience. The results are summarized in Table 6 (panel B) and indicate that assortment size becomes significant at experience levels of 62 or more. On average, households reach this experience level after about 3 online shopping trips, which is for the average household after about 50 days (average online shopping frequency of 2 times per month) and after having spent on average approximately $453 £$ on groceries online.

Looking at the standard deviations capturing the effect of unobserved household heterogeneity (last column, Table 5), we can conclude that, for a significant number of variables, response parameters differ over households. For instance, while assortment composition has a positive and significant effect for the majority of the households, this does not hold for the entire estimation sample (no positive effect for approximately $13 \%$ of the households ${ }^{10}$ ). For other variables, such as online store loyalty, the magnitude of the effect varies across households, but is significant (and has the same sign) for all households. Although the already negative effect of

\footnotetext{
${ }^{10}$ This percentage with an opposite sign as the average parameter is calculated as: $100-100 * \Phi\left(-\beta_{-}\right.$mean $\left./ \beta_{-} S D\right)$.
} 
assortment integration becomes significantly stronger for households at minus one standard deviation of the distribution $\left(\beta_{5-1 \mathrm{SD}}=-6.28 ; \mathrm{p}<.01\right)$, we know from the interaction effects that this should be cautiously interpreted as only the households with a zero offline store preference have a negative coefficient for assortment integration. Moreover, for $2 \%$ of the households, assortment integration has a positive influence on online store choice. Concerning the interaction effects with online buying experience, we notice that the moderating effect of experience on online store loyalty is positive and significant for the majority of the households (72\%), and for offline store preference negative and significant for almost all households (97\%).

To gain some insights in the relative importance of store choice drivers on online store choice probabilities, we simulate the effects of a $10 \%$ improvement in assortment size and composition on online store choice probabilities. Appendix A provides an overview of the simulation procedure and results. An increase in online assortment size (number of brands + 10\%) has no significant impact when consumers have no or limited online buying experience, but substantially increases the store's choice probability at higher levels of experience (up to 12.55\% and 29.03\% increase in choice probability for Waitrose, at mean and high levels of experience respectively; upper part of Table A.1 in Appendix A). Assortment composition has a positive effect on store choice probability, which is not influenced by online buying experience. When more favorite brands are available in the online store (assortment composition improvement of $10 \%$ ), the online store choice probability increases with $2.70 \%$ (Tesco) to $5.50 \%$ (Sainsbury's) (lower part of Table A.1 in Appendix A). Hence, retailers can attract (or retain) more experienced online grocery shoppers by increasing the number of brands in the online assortment, and - independent of experience - by making more favorite brands available in the online store (e.g., by focusing on high market share brands). 


\section{Robustness checks}

To check whether our model results are robust, several alternative models are tested and compared. First, we re-estimated our model on a subset of the original dataset (i.e., randomly selected $80 \%$ of the observations), and obtained the same substantive findings. Second, as Waitrose online is a combination of Waitrose and Ocado, the store may seem to be a-typical, compared to the other three multi-channel retailers. Therefore, analyses were redone without Waitrose in the dataset, thus excluding Waitrose as a choice option and those observations where Waitrose online was chosen. These analyses did not result in substantively different findings; hence we decided to keep Waitrose in the model.

Third, we also tested the sensitivity of our results to the selected variables in our model. While eliminating a particular variable (e.g., assortment integration) influences closely related variables (especially interaction effects between assortment integration and offline store preference or experience), parameters and corresponding significance levels of other variables were hardly affected. Fourth, we used a grid procedure to derive the optimal values for the decay parameters of the online store loyalty and online buying experience variables. Estimations with values of the decay parameters within a reasonable range around the selected values provided almost identical results. We also tested other operationalizations of the online buying experience variable (a simple count rather than a dynamic measure; and a measure based on recency and frequency only) and found strong support for our selected measure in terms of model fit.

We further included trend interactions with all store choice drivers (i.e., price, assortment size, assortment composition, online store loyalty, offline store preference, price and assortment integration). Although there were two trend coefficients significant (i.e., Trend*Online store 
loyalty; Trend*Price integration) out of the 7 interactions, the substantive results remained almost identical and we decided to report the simpler model without trend interactions in our paper. Lastly, to disentangle whether the online buying experience effects are driven by betweenhousehold differences rather than within-household differences over time, we included a household mean of the online grocery buying experience in the model as an extra variable (based on Enders \& Tofighi 2007). While the same substantive findings are obtained for key variables, the model fit is substantially lower (BIC of model with average household experience: 18847.04 vs. BIC of original model: 18832.59). This implies that the experience effects are strongly driven by changes over time rather than over households.

\section{Online store loyalty model}

The focus in this study is on deriving insights into the (changing) effects of key online store choice drivers. In this sense, it is also instructive and managerially relevant to examine which factors influence the development of online store loyalty. Although our store choice model results show that the impact of online store loyalty on online store choice increases with growing online shopping experience (see significant effect of Online loyalty*Experience in Table 5), the level of online loyalty might also evolve over time and with experience.

Previous research points to a declining effect of store loyalty in the online channel. Ansari et al. (2008) and Konuş et al. (2014) discuss the decline of consumers' loyalty in the online channel, and Van Baal and Dach (2005) state that many consumers switch retailers when going online. Moreover, Dawes and Nenycz-Thiel's (2014) study shows that the tendency to visit multiple online retailers increases over time. Our results also indicate that $35.62 \%$ of multichannel shoppers switch grocery chains online (see Table 2). This raises the question what 
factors drive consumers' online store loyalty, and even more important, whether and how it changes over time and when consumers gain more online experience. To more formally address these questions, a supplementary model is estimated where we regress online store loyalty against its potential drivers (i.e., price, assortment size, assortment composition and their interactions with experience), as well as time (captured by a store-specific trend variable) and a store-specific experience variable. We also include a lagged online store loyalty variable to capture carry-over effects from one period to the next one. Table 7 provides an overview of the estimation results for the online store loyalty model.

\section{[Insert Table 7 about here]}

The results indicate that there is a high tendency to remain loyal to the same online store indicated by the strong positive effect of lagged online store loyalty $(.90, \mathrm{p}<.01)$. At the same time, while small in magnitude, the results also demonstrate that for each chain there is a general tendency for online loyalty to decrease over time (significant and negative trend coefficients varying between -.001 for Asda and Waitrose, and -.005 for Tesco). In contrast, the findings indicate that online loyalty decreases with experience for some chains (Waitrose: $-.0002, \mathrm{p}<.01$ ), and increases for others (Asda: .0002, $\mathrm{p}<.01$; Sainsbury's: .00004, $\mathrm{p}<.01$ ) or remains at the same level (market leader Tesco:-.0001, p>.05). Hence, interestingly, the potential decline or rise in online store loyalty at increasing levels of experience is strongly chain-dependent. Moreover, price has a negative effect on online loyalty $(-.03, \mathrm{p}<.01)$, but this effect decreases with higher levels of online buying experience (.0003, $\mathrm{p}<.01)$. Similarly, assortment composition $(.14, \mathrm{p}<.01)$ has a positive effect on online store loyalty, which diminishes with higher levels of online experience $(-.0003, \mathrm{p}<.01)$. Assortment size has no significant effect on online store loyalty $(.01$, $\mathrm{p}>.05)$, at all levels of online buying experience (.0001, $\mathrm{p}>.05)$. In sum, no general conclusion 
can be derived on the increase or decrease in online store loyalty over time, which may depend on several marketing mix instruments as well as the chain positioning as a whole.

\section{Discussion}

Our major research objectives were (i) to provide a systematic and empirical analysis of offlineand online-based drivers of online store choice decisions for groceries, and (ii) to investigate the moderating effect of online buying experience and how it can change the relative importance of these drivers and the resulting store choice decisions. These questions were empirically investigated using a large UK grocery purchase dataset and a traditional multinomial store choice model across all multi-channel retailers in the UK grocery market.

\section{Drivers of online store choice decisions and the moderating effect of experience}

Our results provide clear evidence for the fact that consumers tend to select the online store belonging to the same chain as (one of) their preferred offline store(s) when they start buying groceries online. In the beginning, consumers are less familiar with and uncertain about the online shopping environment, leading them to transfer their offline store preferences to the online channel (Dawes \& Nenycz-Thiel 2014). Moreover, in line with brand extension literature (Bottomley \& Holden 2001), we find that the positive effect of offline store preference on the online store choice probability is stronger when there is a better integration in marketing mix between the online and offline store of the chain. In particular, we find that offering a comparable assortment in the online and offline store strongly improves the transfer of chain preferences and results in a higher likelihood to choose the online alternative of a chain. Stated differently, there is a substantial risk that multi-channel grocery retailers will not be able to 
attract their loyal offline customers to the online store when their online assortment is less aligned with their offline offerings.

The positive transfer effect of offline on online store choice fades over time as consumers gain more online grocery shopping experience. When consumers become more familiar with the online shopping environment and more knowledgeable and confident with the online buying process, their focus shifts from a comparison within chains across the online and offline channel to a comparison within the online channel across chains. First, the strong impact of offline store preference on online store choice loses ground with increased online shopping experience. Second, when experience grows, the online stores' marketing mix - especially assortment size becomes a more important driver of online store choice. Third, the online store loyalty effect becomes stronger when experience increases. Still, even though the importance of online loyalty on the online store choice decision increases, our online store loyalty results indicate that online loyalty as such decreases over time and, for some retailers, even when experience increases.

In sum, the offline environment is important when consumers start to shop in the new online channel, however becomes less important in favor of the online environment when consumers get familiar with online grocery shopping. This shift from offline to online marketing mix comparisons and from offline store preference to online store loyalty when experience increases is in line with previous research on the risk and uncertainty reducing effect of online shopping experience and its impact on online purchase behavior (Gupta \& Kim 2007; Kim \& Gupta 2009).

In this research, no significant effect of price is found: neither in online price level nor in online-offline integration in price level. The absence of significant effects of price and price integration can be the result of a lack of variation of these variables over time, and the fact that 
the store intercepts capture time-invariant differences in attractiveness across stores. Chain differences in price position can be incorporated in - and difficult to disentangle from - intrinsic chain preference effects. In addition, while previous research also pointed to lower price sensitivity in the online compared to the offline channel (Chu et al. 2008; Chu et al. 2010; Zhang \& Breugelmans 2012), there can be other mechanisms in an online store's pricing strategy that affect consumers' purchase behavior. For instance, delivery or pick-up fees and assortment organization in the online store (default order, by price or by brand) can differ across online retailers, which could change the perception of the online store's price level in general (Suri, Zhen Cai, \& Monroe 2012). Also, the included price variables are computed over regular store prices and do not reflect the possible impact of temporary price promotions. Due to a lack of information on these aspects, we cannot control for their effect in the current analysis.

\section{Implications for multi-channel retailers}

The estimation results and previous discussion indicate that multi-channel retailers should be careful in assuming that their loyal offline customers will select ànd remain with their store when buying groceries online. Substantial differences between the online and offline store, or a less competitive online offer, may lead loyal customers to select - or switch to - a competing online store, especially when their online buying experience increases. In order to retain offline loyal consumers in the online channel, retailers have to make sure that the online assortment matches the offline assortment. By increasing assortment integration, retailers can reduce consumers’ perceived risks and uncertainty of buying groceries in the new online store. This reinforces the 'transfer in preference' effect from the offline to the online channel, which is especially important when consumers start to buy groceries online. 
Second, when gaining more online buying experience, satisfied online shoppers may develop loyalty to the online store, reinforcing the tendency to revisit this store online. Our online loyalty model indicates that online store loyalty is positively influenced by assortment composition. Assortment is therefore not only a critical driver because of its direct effect on online store choice decisions, it also increases the probability that consumers will revisit the store through its positive impact on online store loyalty.

Third, multi-channel retailers should take the change in decision process, when consumers gain more online buying experience, into account when planning their marketing mix strategy. Although we do not find any significant effect for price, the results demonstrate that assortment has an important but changing effect on consumers' online store choice decisions. While alignment of the online and offline assortment is crucial in the initial ('trial') stages of the online buying process, its importance as a competitive online marketing instrument increases as consumers gain more online buying experience. This adds to the complexity of the multi-channel retail strategy (account for within- as well as cross-channel effects), but at the same time, opens up opportunities to better retain loyal customers and attract new customers.

\section{Limitations and future research}

Further research can build upon the findings of this study and extend it in several ways. First, we conducted our analysis ignoring product category differences. However, previous research has indicated that the tendency to buy groceries online can differ substantially across product categories (Chintagunta et al. 2012; Campo et al. 2014). As this can also affect the relative attractiveness of different online stores, it would be interesting to examine the role of product categories in future online store choice research. 
In addition, while the rich and large panel data set allows us to obtain insights in household level store choice decisions and the moderating effect of online buying experience, it also entails some constraints. For one, we use behavioral measures to operationalize our variables, which may not completely capture consumers’ perceptions and beliefs (Bell et al. 1998; Burton 2003; Suri et al. 2012). It would therefore be valuable to gather additional perceptual data as well as to examine the effect of experience on mediating variables such as the perceived online buying risk. Next, we have no information on promotions run in the online stores or on other external events (for instance, dissatisfaction because of a service failure, or a change in service delivery policy) that may stimulate consumers to switch online stores. Future research should incorporate these aspects in the store choice model. Finally, behavioral measures limit the possibility to capture changes in price and assortment over time, because infrequent purchases of some brands can reduce the reliability of time-specific assortment and price measures.

Third, in this research, no effect of price is found: neither in online price level nor in online-offline integration in price level. While this result is in line with previous research reporting low(er) price sensitivity in online grocery stores, it would be worthwhile to investigate online price effects in more detail to test alternative explanations (such as the impact of delivery fees, merchandising effects, promotional price reductions, differences in price sensitivity across categories). Another factor that would be interesting to include in future research is the impact of distance on online store choice. Although distance to a store is less important in the online channel (Brynjolfsson \& Smith 2000), especially because there was no pick-up (only home delivery) in our estimation period, distance to a store still might have an effect on online store choice. This may be especially the case when online shopping opens up opportunities to visit 
chains that are otherwise difficult to reach (large distance between the consumer's home and the offline store), or when multi-channel retailers provide a pick-up service (distance to the pick-up point).

Fourth, a more systematic investigation of why online store loyalty decreases for some chains but increases for others when consumers gain more online grocery shopping experience would be a very valuable avenue for future research. Our preliminary results seem to be in line with the size of the retailers, namely that the smallest players in the market, such as Waitrose, need to exert more effort to gain consumers’ increased loyalty, while market leaders, such as Tesco have little to gain from increased effort. Nevertheless, these suggestions need further investigation. Other fascinating areas for future research are the comparison between online and offline store loyalty, an investigation of whether and how online loyalty influences offline shopping behavior and whether and how online grocery shopping influences spending allocation.

Lastly, we could refine our model by using a nested logit model structure, where we first model the decision to shop online or offline and next focus on which online store to choose given an online visit. Because of the lack of situational and context information (e.g. a consumer's time constraints, his/her need for shopping convenience, temporary price reductions and online advertising), we decided to treat the online channel visit decision as given and rather focused on the online store choice decision only. Extending the online store choice model with channel choice decisions could improve our understanding of online shopping behavior and provide useful additional guidelines for multi-channel grocery retailers. 


\section{Appendix A: Simulations}

To simulate the impact of a change in one of the marketing mix variables on online store choice, we use the actual data set as a starting base, i.e., we use the actual values of the explanatory variables (with the exception of offline store preference) and the estimated (mean) parameters of the model to compute (i) benchmark utility and store choice probability values. We then systematically change the values of the major marketing mix variables, and re-compute (ii) the stores' utility levels and choice probabilities. The \% change between (i) and (ii) indicates the impact of a change in major marketing mix variables, given the store's current shopper's profile. For offline store preference, we use the average levels of offline store preference for each store (=.69), as households with this level of offline store preference are most likely to choose the online store of their offline preferred chain. Moreover, due to the analysis method (multinomial choice model), offline store preference equals zero in many cases, which would result in low percentage changes if we would use the values as observed in our dataset.

Table A.1 reports the simulation results. We focus on assortment size and composition as our estimation results point out that the price variable does not have a significant impact on online store choice. We separately estimate the effect of a $10 \%$ increase in assortment size, and a 10\% improvement in assortment composition (through inclusion of more favorite brands). It follows that the results of these simulations are rather conservative, as increasing one assortment component probably influences other assortment components as well. For example, increasing online assortment size possibly also increases the availability of favorite brands (assortment composition). Hence, the actual benefits from adjusting the online store's assortment may even be higher than what is reported here. Because assortment size effects vary with the level of online grocery shopping experience (cf. estimation results), we compute the impact of the $10 \%$ 
increase in assortment size for different experience levels (Table A.1, upper part), while this was not done for assortment composition as this variable does not depend on experience (Table A1, lower part).

Table A.1: Impact of assortment on online store choice probabilities

\begin{tabular}{|c|c|c|c|c|}
\hline & Asda & Sainsbury's & Tesco & Waitrose \\
\hline \multicolumn{5}{|c|}{ Impact of assortment size $+10 \%$, at different levels of experience $e^{\mathrm{a}}$} \\
\hline Low experience & $.00 \%$ & $.00 \%$ & $.00 \%$ & $.00 \%$ \\
\hline Mean experience & $+1.36 \% *$ & $+.53 \% *$ & $+4.85 \% *$ & $+12.55 \% *$ \\
\hline High experience & $+2.96 \% * *$ & $+1.13 \% * *$ & $+10.29 \% * *$ & $+29.03 \% * *$ \\
\hline \multicolumn{5}{|c|}{ Impact of assortment composition $+10 \%$} \\
\hline & $+6.09 \% * *$ & $+6.50 \% * *$ & $+2.70 \% *$ & $+5.21 \% * *$ \\
\hline
\end{tabular}

${ }^{\mathrm{a}}$ Low experience $=0$, High experience $=$ mean $+1 \mathrm{SD}$.

We set the low level of experience equal to zero (which is the situation where a household buys groceries online for the first time), because the 'mean - 1SD' results in a negative experience value.

${ }^{*} \mathrm{p}<.05, * * \mathrm{p}<.01$ (two-sided $\mathrm{p}$-values). 


\section{Acknowledgments}

The authors thank AiMark for providing the data and greatly appreciate the valuable suggestions by the editor and the anonymous JR reviewers. Special thanks go to Prof. Dr. Marnik G.

Dekimpe for pointing to relevant issues leading to improvements in this article. The authors also acknowledge financial support from the National Bank of Belgium (NBB) under grant number

NBB.14.004.

\section{References}

Alba, J. W., \& Hutchinson, J. W. (1987). Dimensions of Consumer Expertise. Journal of Consumer Research, 13(4), 411-454.

Andrews, R. L., \& Currim, I. S. (2004). Behavioural Differences Between Consumers Attracted To Shopping Online Versus Traditional Supermarkets: Implications For Enterprise Design And Marketing Strategy. International Journal of Internet Marketing and Advertising, 1(1), 38-61.

Ansari, A., Mela, C. F., \& Neslin, S. A. (2008). Customer channel migration. Journal of Marketing Research, 45(1), 60-76.

Bawa, K., \& Ghosh, A. (1999). A Model of Household Grocery Shopping Behavior. Marketing Letters, 10(2), 149-160.

Bell, D. R., Ho, T.-H., \& Tang, C. S. (1998). Determining Where to Shop: Fixed and Variable Costs of Shopping. Journal of Marketing Research, 35(3), 352-369.

Berger, P. D., Lee, J., \& Weinberg, B. (2006). Optimal Cooperative Advertising Integration Strategy for Organizations Adding a Direct Online Channel. Journal of the Operational Research Society, 57(8), 920-927.

Bottomley, P. A., \& Holden, S. S. (2001). Do We Really Know How Consumers Evaluate Brand Extensions? Empirical Generalizations Based on Secondary Analysis of Eight Studies. Journal of Marketing Research, 38(4), 494-500.

Briesch, R. A., Chintagunta, P., \& Fox, E. J. (2009). How Does Assortment Affect Grocery Store Choice? Journal of Marketing Research, 46(2), 176-189.

Brynjolfsson, E., \& Smith, M. D. (2000). Frictionless Commerce? A Comparison of Internet and Conventional Retailers. Management Science, 46(4), 563-585.

Buckinx, W., \& Van den Poel, D. (2005). Customer Base Analysis: Partial Defection of Behaviourally Loyal Clients in a Non-Contractual FMCG Retail Setting. European Journal of Operational Research, 164(1), 252-268.

Burton, S. (2003). Reality or Perception? The Effect of Actual and Perceived Performance on Satisfaction and Behavioral Intention. Journal of Services Research, 5(4), 292-302.

Campo, K., Breugelmans, E., \& He, H. (2014). An Empirical Analysis of the Impact of Cross-Channel Promotions in Multi-Channel Grocery Retailing (KU Leuven Working Paper).

Carini, A., Vikram, S., Patti, F. E., \& Doug, R. (2011). European Online Retail Forecast, 2010 To 2015: eCommerce Continues To Grow In Overall Importance To The Retail Landscape In Europe In F. Research (Ed.). Retrieved November 102014 from http://www.forrester.com/European+Online+Retail+Forecast+2010+To+2015/fulltext/-/E$\underline{\text { RES58597 }}$ 
Cheng, J. (2010). The New Age of Online Grocery Shopping. Retrieved November 102014 from http://arstechnica.com/business/2010/03/the-new-age-of-online-grocery-shopping/

Chintagunta, P., Chu, J., \& Cebollada, J. (2012). Quantifying Transaction Costs in Online/Off-line Grocery Channel Choice. Marketing Science, 31(1), 96-114.

Chu, J., Arce-Urriza, M., Cebollada, J., \& Chintagunta, P. (2010). An Empirical Analysis of Shopping Behavior Across Online and Offline Channels for Grocery Products: The Moderating Effects of Household and Product Characteristics. Journal of Interactive Marketing, 24(4), 251-268.

Chu, J., Chintagunta, P., \& Cebollada, J. (2008). Research Note-A Comparison of Within-Household Price Sensitivity Across Online and Offline Channels. Marketing Science, 27(2), 283-299.

Clark, S. H. (2014). Why 2014 Will Finally Be the Year of the Online Grocer. Retrieved November 10 2014 from http://www.businessweek.com/articles/2014-01-16/why-2014-will-finally-be-the-yearof-the-online-grocer

Dawes, J., \& Nenycz-Thiel, M. (2014). Comparing Retailer Purchase Patterns and Brand Metrics for InStore and Online Grocery Purchasing. Journal of Marketing Management, 30(3-4), 364-382.

Degeratu, A. M., Rangaswamy, A., \& Wu, J. (2000). Consumer Choice Behavior in Online and Traditional Supermarkets: The Effects of Brand Name, Price, and Other Search Attributes. International Journal of Research in Marketing, 17(1), 55-78.

DelVecchio, D. (2000). Moving Beyond Fit: the Role of Brand Portfolio Characteristics in Consumer Evaluations of Brand Reliability. Journal of Product \& Brand Management, 9(7), 457-471.

Enders, C. K., \& Tofighi, D. (2007). Centering Predictor Variables in Cross-Sectional Multilevel Models: a New Look at an Old Issue. Psychological methods, 12(2), 121-138.

Fox, E. J., Montgomery, A. L., \& Lodish, L. M. (2004). Consumer Shopping and Spending across Retail Formats. The Journal of Business, 77(2), 25-60.

Guadagni, P. M., \& Little, J. D. C. (2008). A Logit Model of Brand Choice Calibrated on Scanner Data: A 25th Anniversary Perspective. Marketing Science, 27(1), 29-48.

Gefen, D., Karahanna, E., \& Straub, D. W. (2003). Trust and TAM in Online Shopping: an Integrated Model. MIS quarterly, 27(1), 51-90.

Gijsbrechts, E., Campo, K., \& Nisol, P. (2008). Beyond Promotion-Based Store Switching: Antecedents and Patterns of Systematic Multiple-Store Shopping. International Journal of Research in Marketing, 25(1), 5-21.

Grewal, D., Janakiraman, R., Kalyanam, K., Kannan, P. K., Ratchford, B., Song, R., \& Tolerico, S. (2010). Strategic Online and Offline Retail Pricing: A Review and Research Agenda. Journal of Interactive Marketing, 24(2), 138-154.

Grewal, D., Kopalle, P., Marmorstein, H., \& Roggeveen, A. (2012). Does Travel Time Matter? The Role of Merchandise Availability. Journal of Retailing, 88(3), 437-444.

Gupta, S., \& Kim, H.-W. (2007). The Moderating Effect of Transaction Experience on the Decision Calculus in On-line Repurchase. International Journal of Electronic Commerce, 12(1), 127-158.

Hartman Group (2012). The Online Grocery Shopper: Exploring Emerging Opportunities and Ways to Engage More Consumers in a New Era of Digital Technology. Retrieved November 102014 from http://www.hartman-group.com/downloads/online-grocery-shopper-study-2012.pdf

Hogarth, R. M., \& Einhorn, H. J. (1992). Order Effects in Belief Updating: The Belief-Adjustment Model. Cognitive Psychology, 24(1), 1-55.

Hoyer, W. D., MacInnis, D. J., \& Pieters, R. (2013). Consumer Behavior (6th ed.). South Western: Cengage Learning.

IGD (2012). The Connected Shopper. Retrieved November 102014 from http://www.igd.com/our-expertise/Shopper-Insight/shopper-outlook/4136/TheConnected-Shopper/

Jaccard, J., Wan, C. K., \& Turrisi, R. (1990). The Detection and Interpretation of Interaction Effects between Continuous Variables in Multiple Regression. Multivariate Behavioral Research, 25(4), 467-478. 
Johnson, E. J., Moe, W. W., Fader, P. S., Bellman, S., \& Lohse, G. L. (2004). On the Depth and Dynamics of Online Search Behavior. Management Science, 50(3), 299-308.

Kim, H.-W., \& Gupta, S. (2009). A Comparison of Purchase Decision Calculus Between Potential and Repeat Customers of an Online Store. Decision support systems, 47(4), 477-487.

Konuş, U., Neslin, S. A., \& Verhoef, P. C. (2014). The Effect of Search Channel Elimination on Purchase Incidence, Order Size and Channel Choice. International Journal of Research in Marketing, 31(1), 49-64.

Koo, D.-M. (2006). The Fundamental Reasons of E-consumers' Loyalty to an Online Store. Electronic Commerce Research and Applications, 5(2), 117-130.

Kushwaha, T., \& Shankar, V. (2013). Are Multichannel Customers Really More Valuable? The Moderating Role of Product Category Characteristics. Journal of Marketing, 77(4), 67-85.

Leenheer, J., Van Heerde, H. J., Bijmolt, T. H., \& Smidts, A. (2007). Do Loyalty Programs Really Enhance Behavioral Loyalty? An Empirical Analysis Accounting for Self-Selecting Members. International Journal of Research in Marketing, 24(1), 31-47.

Montoya-Weiss, M. M., Voss, G. B., \& Grewal, D. (2003). Determinants of Online Channel Use and Overall Satisfaction with a Relational, Multichannel Service Provider. Journal of the Academy of Marketing Science, 31(4), 448-458.

Mulpuru, S., Seghal, V., Freeman Evans, P., Hoar, A., \& Roberge, D. (2012). US Online Retail Forecast, 2011 To 2016. Retrieved November 102014 from http://www.forrester.com/US+Online+Retail+Forecast+2011+To+2016/fulltext/-/ERES60672?intcmp=blog:forrlink\&docid=60672\&src=RSS_2\&cm_mmc=Forrester-_-RSS-_Document- - 23

Neslin, S. A., Grewal, D., Leghorn, R., Shankar, V., Teerling, M. L., Thomas, J. S., \& Verhoef, P. C. (2006). Challenges and Opportunities in Multichannel Customer Management. Journal of Service Research, 9(2), 95-112.

Neslin, S. A., \& Shankar, V. (2009). Key Issues in Multichannel Customer Management: Current Knowledge and Future Directions. Journal of Interactive Marketing, 23(1), 70-81.

Nielsen (2012). Three-quarters of UK Consumers use the Internet for Grocery Shopping: Nielsen.

Pan, Y., \& Zinkhan, G. M. (2006). Determinants of Retail Patronage: a Meta-Analytical Perspective. Journal of Retailing, 82(3), 229-243.

Rankin, J. (2013, March 8). Online Grocery Shopping: When will Morrisons Come in from the Cold?, The Guardian. Retrieved November 102014 from http://www.guardian.co.uk/business/2013/mar/08/morrisons-online-grocery-shopping

Rhee, H., \& Bell, D. R. (2002). The Inter-Store Mobility of Supermarket Shoppers. Journal of Retailing, 78(4), 225-237.

Rose, S., Clark, M., Samouel, P., \& Hair, N. (2012). Online Customer Experience in E-retailing: an Empirical Model of Antecedents and Outcomes. Journal of Retailing, 88(2), 308-322.

Shankar, V., Smith, A.K., \& Rangaswamy, K. (2003). Customer Satisfaction and Loyalty in Online and Offline Environments. International Journal of Research in Marketing, 20(2), 153-175.

Sullivan, M. W. (1998). How Brand Names Affect the Demand for Twin Automobiles. Journal of Marketing Research, 35(2), 154-165.

Steiman, H. C. (2014). Why 2014 Will Finally Be the Year of the Online Grocer. Retrieved November 10 2014, http://www.businessweek.com/articles/2014-01-16/why-2014-will-finally-be-theyear-of-the-online-grocer

Suri, R., Zhen Cai, J., \& Monroe, K.B. (2012). Retailers’ Merchandise Organization and Price Perceptions. Journal of Retailing, 88(1), 168-179.

Tang, C. S., Bell, D. R., \& Ho, T.-H. (2001). Store Choice and Shopping Behavior: How Price Format Works. California Management Review, 43(2), 56-74.

Van Baal, S., \& Dach, C. (2005). Free riding and Customer Retention across Retailers' Channels. Journal of Interactive Marketing, 19(2), 75-85. 
Verhagen, T., \& van Dolen, W. (2009). Online Purchase Intentions: A Multi-channel Store Image Perspective. Information \& Management, 46(2), 77-82.

Völckner, F., \& Sattler, H. (2006). Drivers of Brand Extension Success. Journal of Marketing, 70(2), 1834.

Vroegrijk, M., Gijsbrechts, E., \& Campo, K. (2013). Close Encounter with the Hard Discounter Entry: A Multiple-Store Shopping Perspective on the Impact of Local Hard-Discounter Entry. Journal of Marketing Research, 50(5), 606-626.

Warschun, M. (2012). A Fresh Look at Online Grocery. Retrieved November 102014 http://www.atkearney.com/paper/-/asset_publisher/dVxv4Hz2h8bS/content/a-fresh-look-atonline-grocery/10192

Zettelmeyer, F., Morton, S.F., \& Silva-Risso, J. (2006). How the Internet Lowers Prices: Evidence from Matched Survey and Automobile Transaction Data. Journal of Marketing Research, 43(2), 168181.

Zhang, J., \& Breugelmans, E. (2012). The Impact of an Item-Based Loyalty Program on Consumer Purchase Behavior. Journal of Marketing Research, 49(1), 50-65.

Zhang, J., Farris, P. W., Irvin, J. W., Kushwaha, T., Steenburgh, T. J., \& Weitz, B. A. (2010). Crafting Integrated Multichannel Retailing Strategies. Journal of Interactive Marketing, 24(2), 168-180. 
Figure 1: Conceptual framework

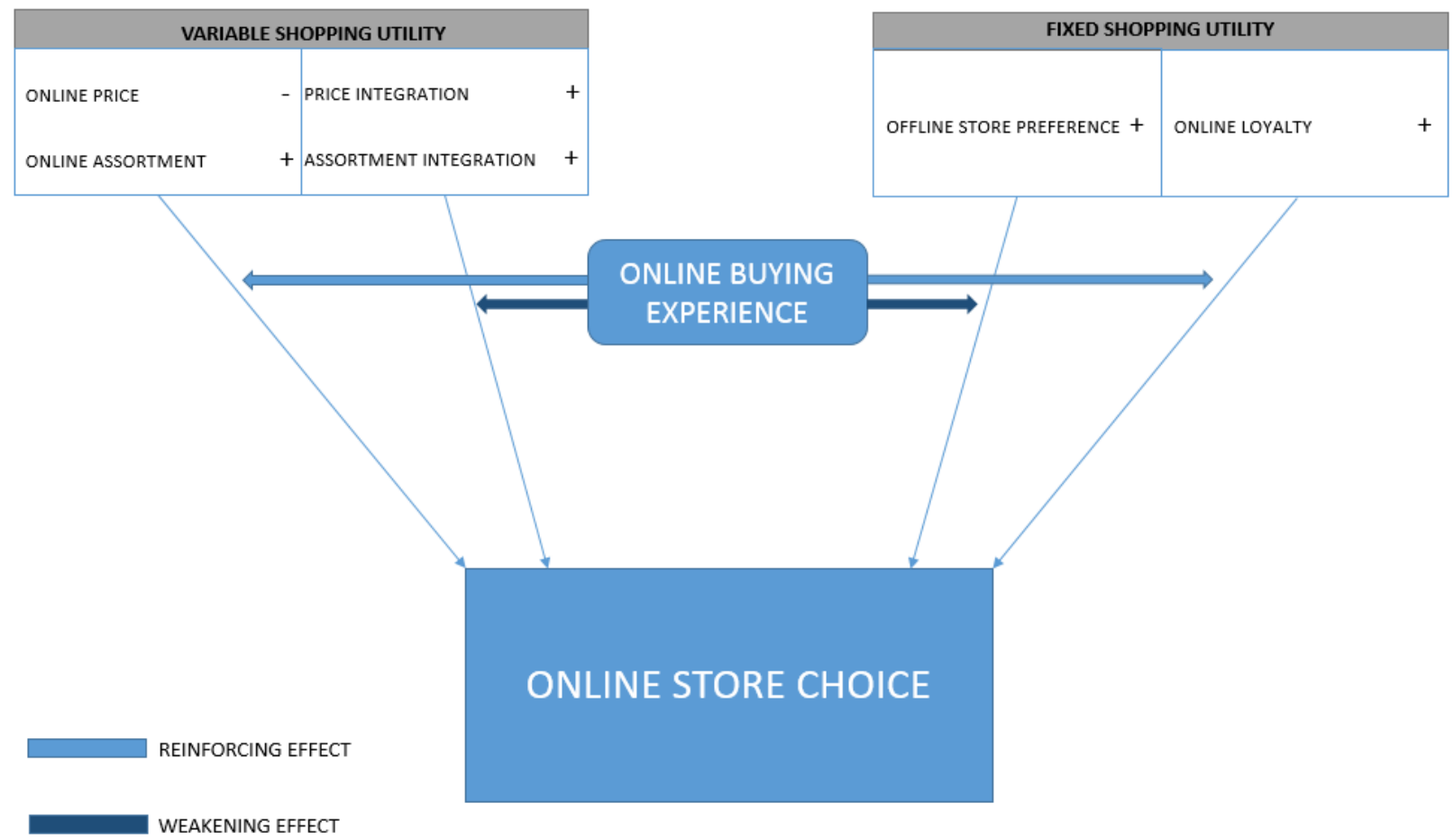


Figure 2: Offline/online market shares of the 4 multi-channel chains in $2007 \& 2008^{a}$

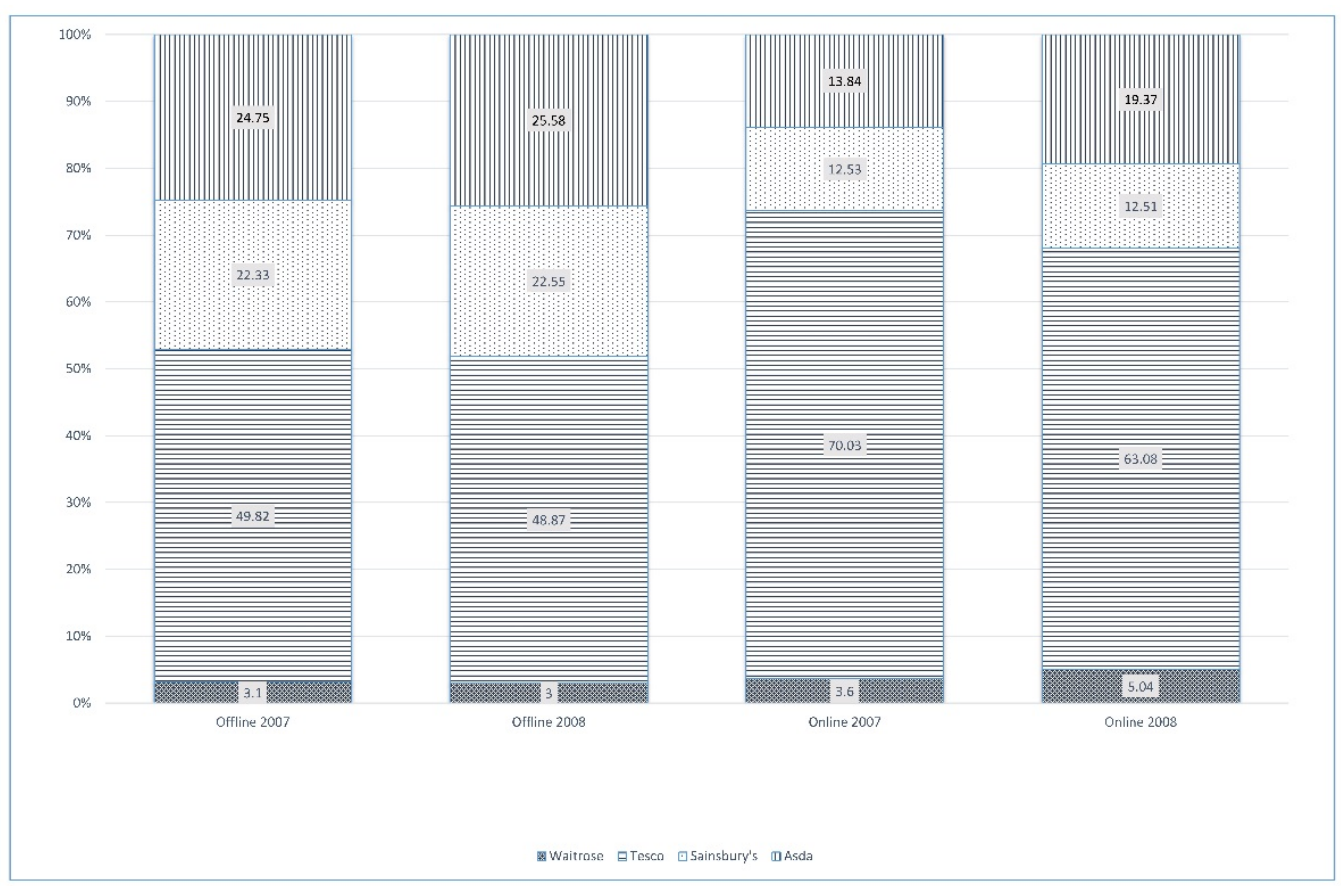

${ }^{\text {a }}$ Offline market shares are calculated using the 4 multi-channel chains only 
Table 1: Literature overview

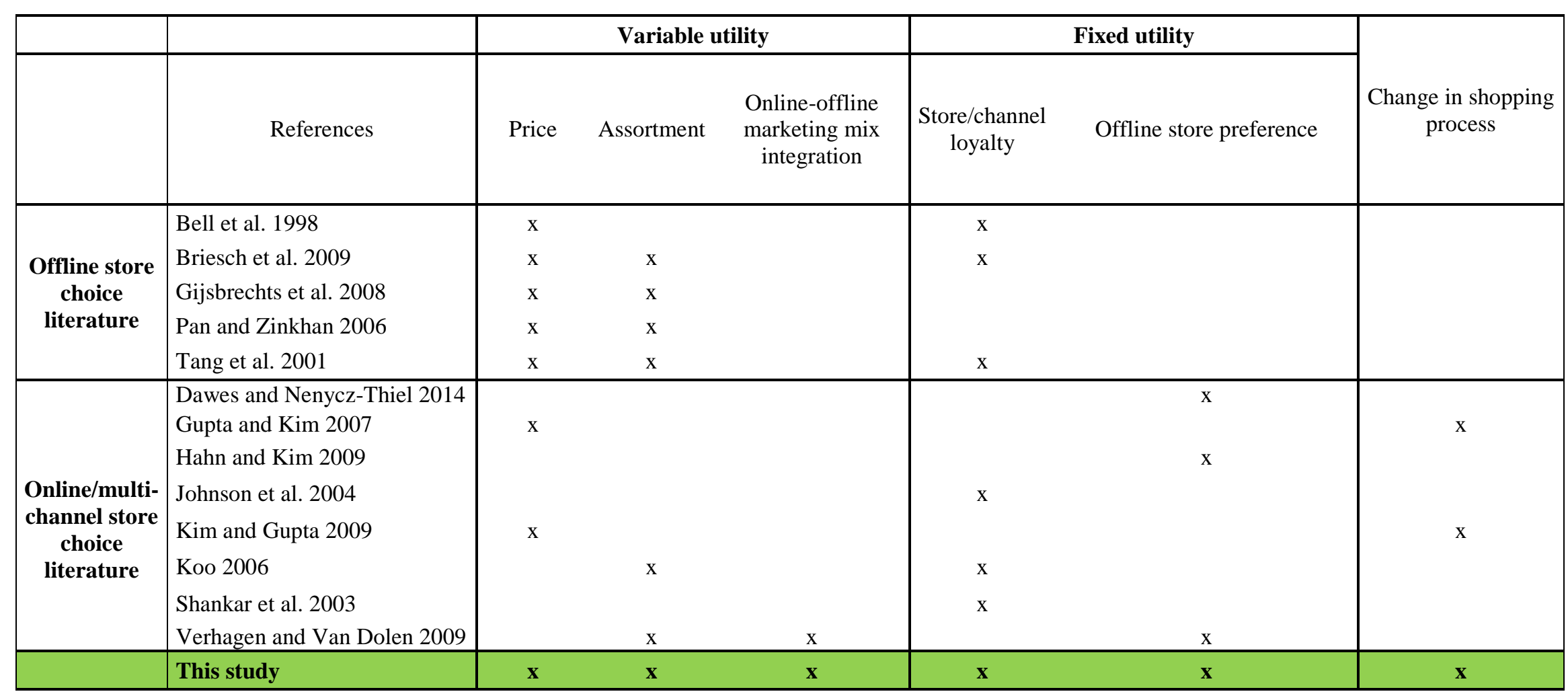


Table 2: Store choice and purchase behavior descriptives

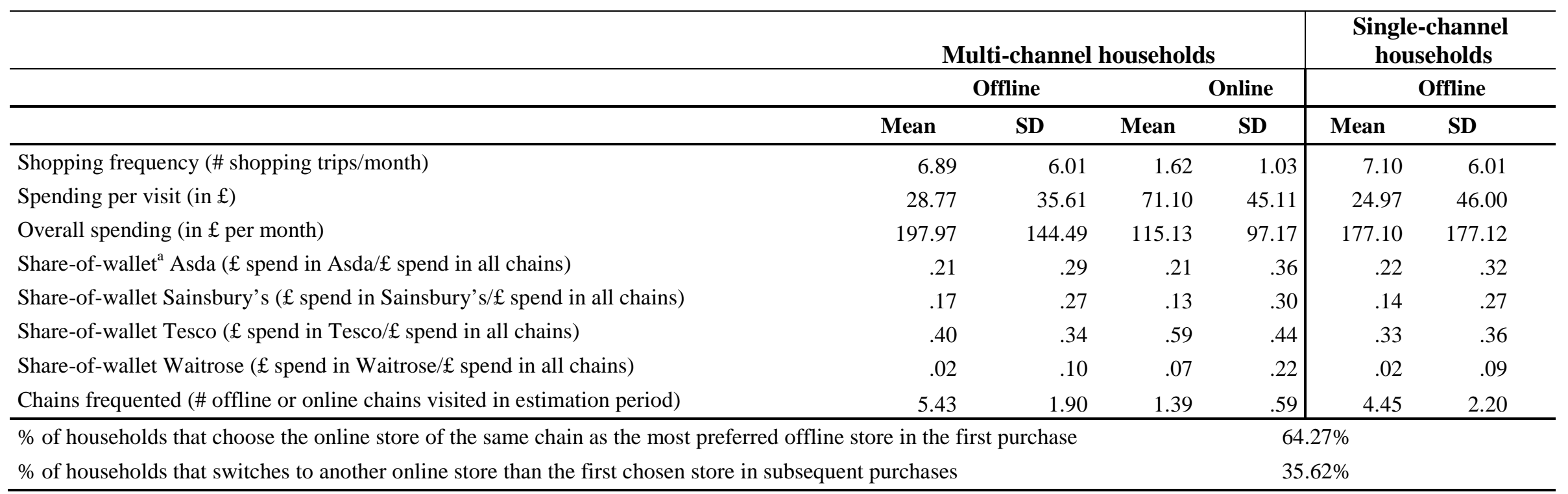

a Share-of-wallet is calculated separately for the online and offline channel, with the inclusion of other single channel retailers in the calculation of the offline share-of-wallet. 
Table 3: Variable operationalization

\begin{tabular}{|c|c|c|c|}
\hline Variable & Description & Based on & Notation \\
\hline $\begin{array}{l}\text { Household } \\
\text { category } \\
\text { share }\end{array}$ & $\begin{array}{l}\text { Category share per household h for each of the } 67 \text { categories c, derived from all online and } \\
\text { offline grocery purchases in the estimation period (i.e., online and offline sales for household h } \\
\text { in category c divided by online and offline sales for household h across all } 67 \text { categories). }\end{array}$ & $\begin{array}{l}\text { Briesch et al. (2009); } \\
\text { Vroegrijk et al. (2013); } \\
\text { Zhang and Breugelmans } \\
\text { (2012) }\end{array}$ & $w_{h c}=\frac{\text { Sales }_{h c}}{\text { Sales }_{h}}$ \\
\hline $\begin{array}{l}\text { Household } \\
\text { brand share }\end{array}$ & $\begin{array}{l}\text { Brand share per household } \mathrm{h} \text { for each of the } 67 \text { categories c, derived from all offline grocery } \\
\text { purchases in the initialization period (i.e., offline sales of household h for brand b divided by } \\
\text { offline sales of household h in category c). }\end{array}$ & Briesch et al. (2009) & $b s_{h b}=\frac{\text { Sales }_{h b}}{\text { Sales }_{h c}}$ \\
\hline Price & $\begin{array}{l}\text { Sum over } 67 \text { categories of the average online unit price across all SKUs in category c for each } \\
\text { period of } 4 \text { weeks in which shopping trip v took place and each store s, standardized to make } \\
\text { comparable across categories and weighted with household category shares. }\end{array}$ & $\begin{array}{l}\text { Fox et al. (2004); Zhang } \\
\text { and Breugelmans } \\
(2012)\end{array}$ & Price $_{h s v}=\sum_{c=1}^{c=67} w_{h c} *$ Online price $c s v$ \\
\hline $\begin{array}{l}\text { Assortment } \\
\text { Size }\end{array}$ & $\begin{array}{l}\text { Sum over } 67 \text { categories of the number of online brands (national brands }+ \text { private labels) in each } \\
\text { category c and for each store s, standardized to make comparable across categories and weighted } \\
\text { with household category shares. }\end{array}$ & Briesch et al. (2009) & $\begin{array}{l}\text { Assortment_size } \\
\text { nr online brands } \\
\text { cs }\end{array}$ \\
\hline $\begin{array}{l}\text { Assortment } \\
\text { Composition }\end{array}$ & $\begin{array}{l}\text { Sum over } 67 \text { categories of the availability of favorite brands (national brands + private labels) in } \\
\text { each category c and for each store s where the availability of a brand b }(1, \ldots, n) \text { is represented } \\
\text { by a dummy variable which is equal to } 1 \text { when brand b of category c is available in store } s \text {, } \\
\text { otherwise } 0 \text {, and weighted with household brand shares to capture household brand preference } \\
\left(\mathrm{bs}_{\mathrm{hb}}\right) \text { and category shares }\left(\mathrm{w}_{\mathrm{hc}}\right) \text {. }\end{array}$ & Briesch et al. (2009) & $\begin{array}{l}\text { Assortment_composition }{ }_{h s}=\sum_{c=1}^{c=67} w_{h c} * \\
\sum_{b=1}^{b=n} b s_{h b} * \text { dummy }_{b c s}\end{array}$ \\
\hline $\begin{array}{l}\text { Price } \\
\text { Integration }\end{array}$ & $\begin{array}{l}\text { Sum over } 67 \text { categories of the ratio of average online unit price over average offline unit price } \\
\text { for a set of SKUs (available in both channels) for each category c in each period of } 4 \text { weeks in } \\
\text { which shopping trip v took place and each store s, weighted with household category shares, and } \\
\text { multiplied by }(-1) \text { to capture integration rather than lack of integration. }\end{array}$ & Sullivan (1998) & $\begin{array}{l}\text { Price_integration }_{h s v}= \\
\left(\sum_{c=1}^{c=67} w_{h c} * \frac{\text { Online price }_{c s v}}{\text { Offline price }}\right) *(-1)\end{array}$ \\
\hline $\begin{array}{l}\text { Assortment } \\
\text { Integration }\end{array}$ & $\begin{array}{l}\text { Sum over } 67 \text { categories of the ratio of the number of online brands (national brands + private } \\
\text { labels) over the number of offline brands (national brands + private labels) for each category c } \\
\text { and store s, and weighted with household category shares. }\end{array}$ & Sullivan (1998) & $\begin{array}{l}\text { Assortment_integration }_{h s} \\
=\sum_{c=1}^{c=67} w_{h c} \frac{n r \text { online brands }}{\text { nr } \text { offline brands }}\end{array}$ \\
\hline $\begin{array}{l}\text { Offline Store } \\
\text { Preference }\end{array}$ & Proportion of offline sales per household $\mathrm{h}$ for each store $\mathrm{s}$ in the initialization period. & Leenheer et al. (2007) & Offline_store_preference ${ }_{h s}=\frac{\text { sales }_{h s}}{\text { sales }_{h}}$ \\
\hline $\begin{array}{l}\text { Online } \\
\text { Loyalty }\end{array}$ & $\begin{array}{l}\text { Weighted sum of loyalty in the previous trip (v-1) for household } \mathrm{h} \text { and store } \mathrm{s} \text { and a last purchase } \\
\text { dummy variable which equals } 1 \text { when the last online purchase was in store } \mathrm{s} \text {, otherwise } 0 \text {, and } \\
\text { weighted with decay parameter } \lambda(.7) \text { to capture fading effects. Starting value=.7 for the store } \\
\text { that is chosen and. } 1 \text { for the other stores. }\end{array}$ & $\begin{array}{l}\text { Campo et al. (2003); } \\
\text { Guadagni and Little } \\
\text { (2008) }\end{array}$ & $\begin{aligned} \text { Online_loyalty }_{h s v} & \\
& =\lambda * \text { Onloy }_{v-1, h s} \\
& +(1-\lambda) * L P_{h s v}\end{aligned}$ \\
\hline Experience & $\begin{array}{l}\text { Weighted sum of previous online purchases (in monetary value) in the estimation period across a } \\
\text { period of } 4 \text { weeks }\left(M_{h, s, p-1}\right) \text { and summed over each of the } 4 \text { stores, where } p \text { is the number of } \\
\text { periods since the first online grocery visit at shopping trip v, and weighted with a decay }\end{array}$ & $\begin{array}{l}\text { Ansari et al. (2008); } \\
\text { Buckinx and Van de } \\
\text { Poel (2005); Campo et }\end{array}$ & $\begin{array}{l}\text { Experience }_{h v} \\
=\sum_{q=1}^{q=v-1} \sum_{s=1}^{s=4} \delta^{p-q} * M_{h, s, p-1}\end{array}$ \\
\hline
\end{tabular}


Table 4: Variable descriptives

\begin{tabular}{lrrrrrrrrr}
\hline & \multicolumn{2}{c}{ Asda } & \multicolumn{3}{c}{ Sainsbury’s } & \multicolumn{2}{c}{ Tesco } & \multicolumn{2}{c}{ Waitrose } \\
& Mean & SD & Mean & SD & Mean & SD & Mean & SD \\
& & & & & & & & \\
\hline Price $^{a}$ & .12 & .38 & .13 & .40 & .13 & .40 & .18 & .53 \\
Assortment_size $^{b}$ & 51.63 & 39.64 & 53.16 & 40.83 & 66.81 & 50.99 & 36.16 & 30.11 \\
Assortment_composition $^{d}$ & .48 & .23 & .47 & .21 & .57 & .26 & .33 & .14 \\
Price_integration $^{a, e}$ & 1.01 & .18 & 1.01 & .21 & 1.02 & .13 & 1.04 & .89 \\
Assortment_integration $^{b}$ & .60 & .11 & .62 & .10 & .64 & .10 & .81 & .14 \\
Online_loyalty $^{c}$ & .19 & .32 & .14 & .27 & .60 & .40 & .07 & .16 \\
Offline_store_preference $^{d}$ & .39 & .35 & .34 & .34 & .53 & .37 & .19 & .27 \\
\hline
\end{tabular}

avariation is a result of differences over categories and periods

bariation is a result of differences over categories

c variation is a result of differences over periods and households

${ }^{\mathrm{d}}$ variation is a result of differences over households

${ }^{\mathrm{e}}$ we report the lack of price integration (i.e., the ratio of online to offline prices or online price premium) 
Table 5: Estimation results online store choice model

\begin{tabular}{|c|c|c|c|c|c|}
\hline \multirow{2}{*}{ INTERCEPTS } & \multirow[t]{2}{*}{ EXPECTED EFFECT } & \multicolumn{4}{|c|}{ ESTIMATES (standard deviation ) } \\
\hline & & \multicolumn{2}{|c|}{ Mean coefficient } & \multicolumn{2}{|c|}{ SD coefficient } \\
\hline Asda $\left(\alpha_{\text {Asda1 }}\right)$ & & $.33 *$ & $(.155)$ & & \\
\hline $\operatorname{Tesco}\left(\alpha_{\text {Tesco1 }}\right)$ & & $.79 *$ & (.369) & & \\
\hline Waitrose $\left(\alpha_{\text {Waitrose } 1}\right)$ & & .98 & $(.641)$ & & \\
\hline \multicolumn{6}{|l|}{ EXPERIENCE } \\
\hline $\operatorname{Asda}\left(\alpha_{\text {Asda2 }}\right)$ & & .0004 & $(.001)$ & & \\
\hline $\operatorname{Tesco}\left(\alpha_{\text {Tesсо } 2}\right)$ & & $-.01 * *$ & $(.004)$ & & \\
\hline Waitrose $\left(\alpha_{\text {Waitrose2 }}\right)$ & & .003 & $(.006)$ & & \\
\hline \multicolumn{6}{|l|}{$\underline{T R E N D}$} \\
\hline Asda $\left(\alpha_{\text {Asda3 }}\right)$ & & .01 & $(.007)$ & & \\
\hline $\operatorname{Tesco}\left(\alpha_{\text {Tеsсо3 }}\right)$ & & $-.01 *$ & $(.006)$ & & \\
\hline Waitrose $\left(\alpha_{\text {Waitrose3 }}\right)$ & & .001 & $(.009)$ & & \\
\hline \multicolumn{6}{|l|}{ MAIN EFFECTS (Experience $=0$ ) } \\
\hline Price $\left(\beta_{1}\right)$ & - & .18 & $(.160)$ & .19 & $(.218)$ \\
\hline Assortment_size $\left(\beta_{2}\right)$ & + & .37 & $(.342)$ & $.30 * *$ & $(.082)$ \\
\hline Assortment_composition $\left(\beta_{3}\right)$ & + & $1.59 * *$ & $(.261)$ & $1.44^{* *}$ & $(.260)$ \\
\hline Price_integration $\left(\beta_{4}\right)$ & + & .46 & $(.568)$ & .91 & $(.599)$ \\
\hline Assortment_integration $\left(\beta_{5}\right)$ & + & $-4.73 *$ & $(2.11)$ & $2.25 *$ & $(.950)$ \\
\hline Online_loyalty $\left(\beta_{6}\right)$ & + & $3.88^{* *}$ & $(.069)$ & $1.08 * *$ & $(.087)$ \\
\hline Offline_store_preference $\left(\beta_{7}\right)$ & + & -2.18 & $(1.44)$ & .01 & $(.144)$ \\
\hline $\begin{array}{l}\text { Offline_store_preference*price_integration }\left(\beta_{8}\right) \\
\text { Offline_store_preference*assortment_integration } \\
\left(\beta_{9}\right)\end{array}$ & $\begin{array}{l}+ \\
+\end{array}$ & $\begin{array}{l}1.14 \\
6.27^{* *}\end{array}$ & $\begin{array}{l}(1.207) \\
(2.11)\end{array}$ & $.64^{* *}$ & $\begin{array}{l}(.176) \\
(.241)\end{array}$ \\
\hline \multicolumn{6}{|l|}{ INTERACTION EFFECTS } \\
\hline Experience*Price $\left(\gamma_{1}\right)$ & - & .001 & $(.001)$ & $.002 * *$ & $(.001)$ \\
\hline Experience*Assortment_size $\left(\gamma_{2}\right)$ & + & $.01 * *$ & $(.003)$ & .0002 & $(.000)$ \\
\hline $\begin{array}{l}\text { Experience*Assortment_composition }\left(\gamma_{3}\right) \\
\text { Experience*Price_integration }\left(\gamma_{4}\right)\end{array}$ & + & $\begin{array}{r}.002 \\
-.004\end{array}$ & $\begin{array}{l}(.002) \\
(.003)\end{array}$ & $\begin{array}{l}.002 \\
.002\end{array}$ & $\begin{array}{l}(.003) \\
(.002)\end{array}$ \\
\hline Experience*Assortment_integration $\left(\gamma_{5}\right)$ & - & -.03 & $(.020)$ & $.03^{* *}$ & $(.005)$ \\
\hline Experience*Online_loyalty $\left(\gamma_{6}\right)$ & + & $.001^{* *}$ & $(.001)$ & $.002 * *$ & $(.001)$ \\
\hline Experience*Offline_store_preference $\left(\gamma_{7}\right)$ & - & $-.002 *$ & $(.001)$ & $.002 * *$ & $(.001)$ \\
\hline \multicolumn{6}{|l|}{ Goodness-of-fit } \\
\hline$\overline{\text { Log Likelihood }}$ & & \multicolumn{4}{|c|}{-9099.69} \\
\hline AIC & & \multicolumn{4}{|c|}{18281.38} \\
\hline BIC & & \multicolumn{4}{|c|}{18673.07} \\
\hline Pseudo R² & & \multicolumn{4}{|c|}{$76.16 \%$} \\
\hline
\end{tabular}

${ }^{*} \mathrm{p}<.05,{ }^{* *} \mathrm{p}<.01$ (two-sided $\mathrm{p}$-values). 


\section{Table 6: Overall interaction effects}

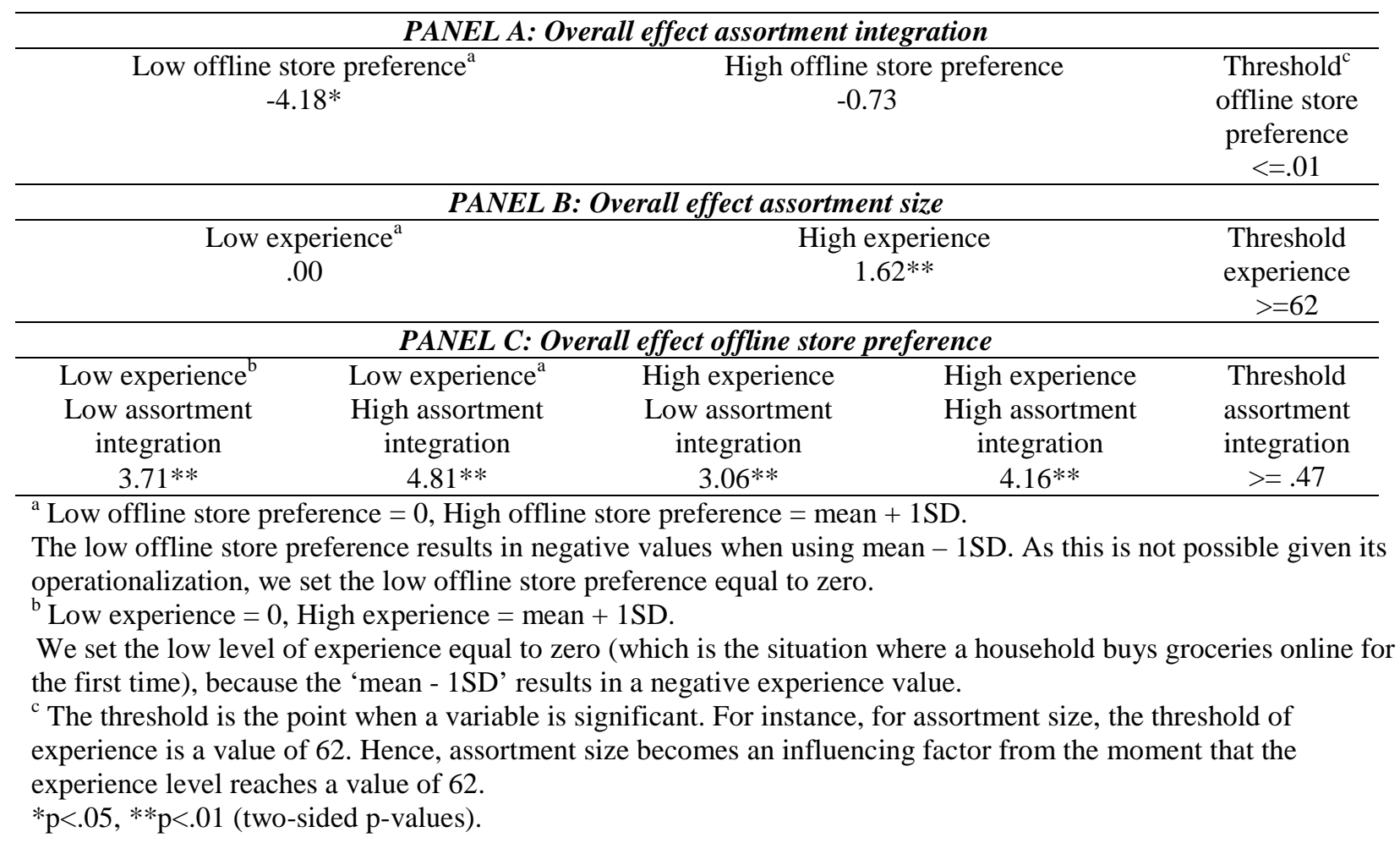


Table 7: Estimation results online store loyalty model

\begin{tabular}{|c|c|c|}
\hline & Mean & $S D$ \\
\hline \multicolumn{3}{|l|}{ INTERCEPTS } \\
\hline Asda & .004 & $(.003)$ \\
\hline Sainsbury's & $.01 * *$ & $(.002)$ \\
\hline Tesco & $.13^{* *}$ & $(.010)$ \\
\hline Waitrose & $.05^{* *}$ & $(.009)$ \\
\hline \multicolumn{3}{|l|}{ EXPERIENCE } \\
\hline Asda & $.0002 * *$ & $(.000)$ \\
\hline Sainsbury's & $.00004^{* *}$ & $(.000)$ \\
\hline Tesco & -.0001 & $(.000)$ \\
\hline Waitrose & $-.0002 * *$ & $(.000)$ \\
\hline \multicolumn{3}{|l|}{$\underline{\text { TREND }}$} \\
\hline Asda & $-.001 * *$ & $(.000)$ \\
\hline Sainsbury's & $-.002 * *$ & $(.000)$ \\
\hline Tesco & $-.005 * *$ & $(.000)$ \\
\hline Waitrose & $-.002^{* *}$ & $(.000)$ \\
\hline \multicolumn{3}{|l|}{ MAIN EFFECTS (Experience $=0$ ) } \\
\hline Price & $-.03 * *$ & $(.002)$ \\
\hline Assortment_size & .01 & $(.008)$ \\
\hline Assortment_composition & $.14^{* *}$ & $(.002)$ \\
\hline \multicolumn{3}{|l|}{ INTERACTION EFFECTS } \\
\hline Experience*Price & $.0002 * *$ & $(.000)$ \\
\hline Experience*Assortment_size & .0001 & $(.000)$ \\
\hline Experience*Assortment_composition & $-.0003 * *$ & $(.000)$ \\
\hline \multicolumn{3}{|l|}{ LAGGED EFFECTS } \\
\hline Lagged online store loyalty & $.90 * *$ & $(.001)$ \\
\hline \multicolumn{3}{|l|}{ Goodness-of-fit } \\
\hline Adjusted R ${ }^{2}$ & \multicolumn{2}{|c|}{$92.21 \%$} \\
\hline
\end{tabular}

${ }^{*} \mathrm{p}<.05,{ }^{* *} \mathrm{p}<.01$ (two-sided $\mathrm{p}$-values). 